\title{
Occurrence of Sugar Alcohols Determines Boron Toxicity Symptoms of Ornamental Species
}

\author{
Patrick H. Brown and Hening Hu \\ Department of Pomology, University of California, Davis, CA 95616 \\ Warren G. Roberts \\ University Arboretum, University of California, Davis, CA 95616
}

AdDitional INDEX wORDs. polyols, boron mobility, dieback, diagnosis, tissue sampling

\begin{abstract}
The phloem mobility of boron (B) in plants varies dramatically among species. Variations in phloem B mobility occur as a consequence of the presence of sugar alcohols (polyols) in some species but not in others, and these differences in phloem B mobility profoundly affect the expression of B toxicity symptoms. Twenty-four species including common ornamental species varying in sugar alcohol content, were selected to test their response to B toxicity. Species that do not produce sugar alcohols exhibited previously described $B$ toxicity symptoms that include accumulation of high concentrations of $B$ in, and burning of, the tip and margin of old leaves. In the sugar-alcohol-producing species these symptoms were absent, and $B$ toxicity was expressed as meristematic dieback and an accumulation of $B$ in apical tissues. These symptoms have not previously been associated with $B$ toxicity in these species and hence may have been frequently misdiagnosed.
\end{abstract}

The typical pattern of B accumulation in plants is for a higher concentration of $\mathrm{B}$ to be found in oldest leaves with progressively lower B concentrations in younger tissues and fruits. This distribution of B is typical of an element with limited phloem mobility and results in the development of leaf tip and margin burn of the oldest leaves as a consequence of the high B concentrations in these tissues (Brown and Shelp, 1997). Eaton et al. (1941) reported, however, that the leaf symptoms of B toxicity, so characteristic in many plants, are frequently absent in stone fruit trees. In support of these observations, other workers have also demonstrated that species of Malus, Prunus, and Pyrus do not accumulate high concentrations of B in their leaves, and that B toxicity is expressed as twig dieback and gum exudation in leaf axils and buds (Choe et al., 1986; El-Motaium et al., 1994; Hansen, 1948, 1955; Maas, 1984; Woodbridge, 1955). These unusual symptoms of B toxicity are the result of the high phloem mobility of B in these species (Brown and $\mathrm{Hu}, 1996$ ), which occurs as a result of the formation and phloem transport of a Bsorbitol complex (Brown and Hu, 1996; Hu et al., 1997). Because sugar alcohols (dulcitol, mannitol, sorbitol, etc.) can easily form complexes with boric acid with no enzymatic requirement (Makkee et al., 1985), and because they represent primary products of photosynthesis in these species, we predict that the B-sugar alcohol complex will be readily transported to active sinks such as apical tissues (Brown and Hu, 1996; Hu et al., 1997). As a result, $\mathrm{B}$ will be accumulated in the meristematic regions or fruit, but not in the mature leaves of species in which sugar alcohols are present. In these species, B toxicity will likely appear in apical and meristematic tissues, while the typical symptoms of B toxicity will not be observed.

As good-quality water for irrigation becomes less abundant, water previously rejected because of high B content will have to be used to meet future agricultural needs (Francois, 1991). Excess $\mathrm{B}$ and salinity are significant problems in California, where $>150,000$ ha in the San Joaquin Valley have been impacted by salinity (Croughan and Rains, 1982). Boron and salt accumulation

Received for publication 8 Sept. 1998. Accepted for publication 15 Mar. 1999. We thank Meiru Wu and David Zeng for their assistance. The cost of publishing this paper was defrayed in part by the payment of page charges. Under postal regulations, this paper therefore must be hereby marked advertisement solely to indicate this fact. are also a potential concern in containerized plant production whenever water with a significant B load is used.

Descriptions of B toxicity symptoms in most modern texts reflect the patterns common in species with limited B mobility and have ignored the unique dieback symptoms of B toxicity expressed in species that produce sugar alcohols (Choe et al., 1986; El-Motaium et al., 1994; Hansen, 1948, 1955; Maas, 1984; Woodbridge, 1955). As a result, the identification of B toxicity in many species is difficult. The present study was initiated to describe B toxicity symptoms in some common ornamentals that vary in sugar alcohol production.

\section{Materials and Methods}

Species commonly used as ornamentals were selected based upon known sugar alcohol production or their taxonomic relationship to other species known to produce sugar alcohols (Bieleski, 1982; Bourne, 1958; Plouvier, 1963; Wallaart, 1980;Zimmermann and Ziegler, 1975). Twenty-three species were purchased from local nurseries in Spring 1997: Angelica gigas L., Antirrhinum L. 'Liberty Mix', Coprosma ×kirkii Forster \& Forster f., Cotoneaster dammeri Medikus. 'Lowfast', Digitalis purpurea L. 'Alba', Eryngium eburneum L., Forsythia Xintermedia Vahl. 'Lynwood', Fragaria L. 'Selva', Galium odoratum L., Gardenia augusta Ellis. 'Veitchiana', Ligustrumjaponicum L. 'Texanum', Maytenus boaria Molina., Olea europaea L. 'Skylark', Osmanthus heterophyllus Lour., Petroselinum crispum Hill., Potentilla alba L. 'Snow White', Punica granatum L. 'Nana', Pyracantha crenatoserrata M. Roemer. 'Graberi', Rhaphiolepis indica Lindley. 'Pinkie', Spiraea prunifolia L., Syringa vulgaris L. 'Lavender Lady', Trachelospermum jasminoides Lemaire., and Veronica austriaca L. subsp. teucrium 'Crater Lake Blue'. In addition, Lycopersicon esculentum Mill. 'Roma VF', a species in which B is immobile (Oertli, 1994) and in which sugar alcohols are absent was included as a control. With the exception of $O$. europaea, which was 2 years old, the woody species used in this experiment were 1-year-old plants. Nonwoody species were 2month-old plants. In this report, we also include photographs of two species, almond [Prunus amygdalus B. Syn. P. dulcis (Mill.)] and walnut (Juglans regia L.), as they develop typical B toxicity symptoms in the field. 
All plants were grown outdoors in a medium of 3 humus $: 2$ peat moss : 3 perlite : 2 sand (by volume) in 19-L pots at Davis, Calif. (38 $33^{\circ}$ ' N latitude, $121^{\circ} 46^{\prime}$ longitude) from 5 Apr. until 16 Oct. 1997. During this period only $3.3 \mathrm{~cm}$ of rain was recorded. Temperature ranged from $4{ }^{\circ} \mathrm{C}$ minimum to $37^{\circ} \mathrm{C}$ maximum in April to June, $11^{\circ} \mathrm{C}$ minimum to $40{ }^{\circ} \mathrm{C}$ maximum in July to August, and $5{ }^{\circ} \mathrm{C}$ minimum and $37^{\circ} \mathrm{C}$ maximum in Sept. to Oct. Full-strength Hoagland's solution no. 1 (Hoagland and Arnon, 1950) was applied to the plants once a week beginning on $11 \mathrm{Apr}$. Iron was supplied at $1.4 \mathrm{mg} \cdot \mathrm{L}^{-1}$ as Fe chelate (Sequestrene-138 $\mathrm{Fe}$ ), and solution $\mathrm{pH}$ was adjusted to 6.0. The B treatment was started on 16 May when all the plants were vigorously growing, and was terminated after 5 months of treatment. Boric acid at 0.5 (control), 5, or $25 \mathrm{mg} \cdot \mathrm{L}^{-1} \mathrm{~B}$, was applied once a week in each nutrient application. At each fertilization, $1 \mathrm{~L}$ of nutrient solution was applied per pot. Each treatment was replicated three times with one plant in each pot, so that each of the 24 species had nine pots. Pots were arranged in a randomized block design. Irrigation with deionized water was made every day except the day of the nutrient application and $1 \mathrm{~d}$ after the application. Visible B toxicity symptoms were recorded as they appeared. Photographs were taken on 8 July and 7 Aug., respectively, depending on the appearance of B toxicity symptoms.

Samples from the organs with B toxicity as well as leaves displaying no toxicity were collected on 25 July or 19 Aug. 1997 from each plant for B determination. Leaf samples of various age categories (from basal to apical) were collected from each plant on 23 Sept. 1997 in the $0.5 \mathrm{mg} \cdot \mathrm{L}^{-1} \mathrm{~B}$ treatment. Boron concentration in leaves along a shoot was used as an indicator of B mobility (Brown and Hu, 1996, 1998; van Goor and van Lune, 1980). For the purpose of this report, leaves in the lowest portion of a shoot were defined as basal leaves, these were all fully matured, relatively old leaves, recently fully expanded leaves were defined as middle leaves; and young, expanding leaves at the top of a shoot were defined as apical leaves. In a few species (see Results and Discussion), all the leaves were fully mature at the time of sampling, in these cases, apical leaves were simply those at the top of a shoot. Leaf samples were collected but were not washed because B is easily leached from leaves during washing procedures (Nyomora et al., 1997). Leaves were dried at $70^{\circ} \mathrm{C}$ for $3 \mathrm{~d}$. Except for the apical tissue, leaf samples were ground to pass 30 mesh screen. All the samples were ashed at $500^{\circ} \mathrm{C}$ for $4 \mathrm{~h}$. After ashing, samples were digested in $1 \%$ nitric acid. Boron concentration in the samples was determined with inductively coupled plasma-mass spectrometry (ICP-MS) as described previously (Brown and $\mathrm{Hu}, 1994)$. Throughout the analysis, borosilicate glass was avoided. Because the primary goal of this experiment was to identify the unique symptoms of B toxicity in these species, fresh weight or dry weight was not measured.

\section{Results and Discussion}

There was a great diversity in sensitivity to B toxicity among the species used. Coprosma, Maytenus, Olea, Punica, and Trachelospermum, were very tolerant of high B supply, and no B toxicity symptoms were observed for the duration of the experiment (5 months) even though the highest B treatment $\left(25 \mathrm{mg} \cdot \mathrm{L}^{-1}\right)$ was sufficient to kill other species. In contrast, other species such as $G$. odoratum were so sensitive that within 1 month of the treatment, B toxicity symptoms were observed even in the $5 \mathrm{mg} \cdot \mathrm{L}^{-1} \mathrm{~B}$ treatment. In this species whole plant death occurred before the end of the experiment in the $25 \mathrm{mg} \cdot \mathrm{L}^{-1} \mathrm{~B}$ treatment.

There were two distinct and species-specific expressions of $B$ toxicity. Classical B toxicities, such as those described in most current textbooks, are exhibited as tip/margin burn in the old leaves. This type of toxicity was observed in Angelica, Eryngium, Forsythia, Fragaria, Galium, Lycopersicon, and Potentilla. However, B toxicity was expressed as death of the apex in species of genera such as Cotoneaster, Digitalis, Gardenia, Ligustrum, Osmanthus, Pyracantha, Rhaphiolepis, and Veronica. Angelica (Fig. 1), Juglans (Fig. 2), and Fragaria (Fig. 3) showed leaf tip burn in oldest leaves. As exposure to B increased, greater portions of the oldest leaves became symptomatic, and symptoms began to appear in leaves of progressively lesser age. In contrast, Gardenia (Figs. 4-5), Prunus (Figs. 6-7), Pyracantha (Fig. 8), Rhaphiolepis (Fig. 9), and Ligustrum (Fig. 10) all showed meristem injury due to B toxicity, and B toxicity in the oldest leaves was only observed in the most advanced stages of toxicity. In Gardenia, the earliest symptom of B toxicity was severe curling of young, growing leaves only (Fig. 4). Leaf tip burn in the older leaves of Gardenia was not observed until B toxicity was advanced and only after significant meristematic damage had occurred (Fig. 5). In almond, B toxicity was exhibited as stem dieback (Figs. 6-7) or gum formation along the main stem; no leaf tip burn was observed. Death of young, growing leaves followed by defoliation of these young leaves was also observed in Pyracantha (Fig. 8), while mature leaves appeared normal. Rhaphiolepis (Fig. 9) resembled Gardenia in symptom expression with B toxicity evidenced by tip burn and defoliation of the youngest leaves. Dieback of shoot tips was also found in Ligustrum with no symptoms evident in mature leaves (Fig. 10).

Table 1 shows the B concentration in leaves expressing moderate B toxicity symptoms and leaves of the same age from control plants. The position of leaves showing B toxicity are also shown. The leaves in which B toxicity was first observed differed among species and were either basal or apical leaves. In no instance were symptoms first expressed in leaves of intermediate position.

In control plants, with no B toxicity symptoms, the B concentrations ranged from 35 to $752 \mu \mathrm{g} \cdot \mathrm{g}^{-1}$ dry weight after 3 to 4 months of $0.5 \mathrm{mg} \cdot \mathrm{L}^{-1} \mathrm{~B}$ treatment (Table 1 ). In most species, $B$ toxicity symptoms were observed when tissue B concentrations ranged from 600 to $1600 \mu \mathrm{g} \cdot \mathrm{g}^{-1}$ dry weight, however in some species B toxicity was exhibited at relatively low leaf B concen-

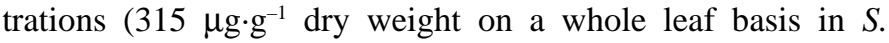
prunifolia), while in others very high concentrations of B were present in leaves exhibiting toxicity, such as $2184 \mu \mathrm{g} \cdot \mathrm{g}^{-1}$ dry weight in L. esculentum resulted in almost whole leaf death of all the old leaves. These differences in B concentration at which B toxicity occurs depended not only on the species, but also on the stage of tissue sampling, and the type of tissue sampled. Boron concentrations vary within leaves in many species (Brown and Shelp, 1997). For example, in blue dracaena [Cordyline indivisa (G. Forst) Steud.] the burned leaf tip contained $8615 \mathrm{mg} \cdot \mathrm{kg}^{-1} \mathrm{~B}$, whereas the remaining tissue contained only $68 \mathrm{mg} \cdot \mathrm{kg}^{-1} \mathrm{~B}$ (Francois and Clark, 1979).

Oertli (1960) suggested that B toxicity symptoms reflect the patterns of B accumulation, and that the occurrence of B toxicity symptoms in old leaves and specifically in the margins and tips of these leaves corresponded to the site of maximal B accumulation. The data presented here support the conclusion that toxicity is related to the local, high $\mathrm{B}$ concentration, but in contrast to Oertli (1960) we have demonstrated that this can occur in leaves either in basal or apical positions, and that this is species dependent. There did not appear to be differences in relative tolerance of apical or basal leaves to B accumulation, because toxicity symptoms were expressed at similar B concentrations in either location. 


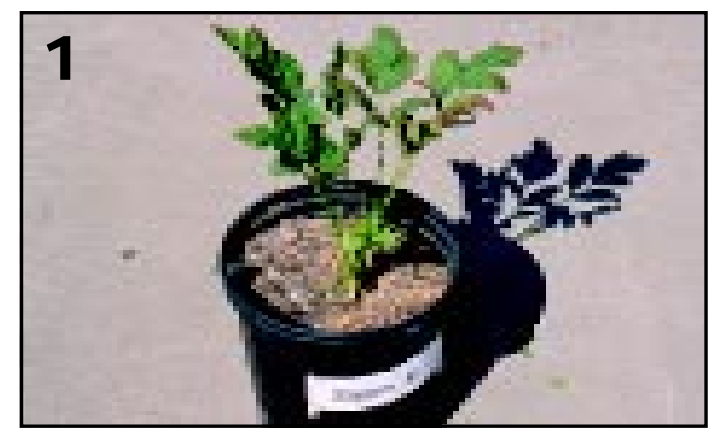

$2^{4}-4+2 y+4$

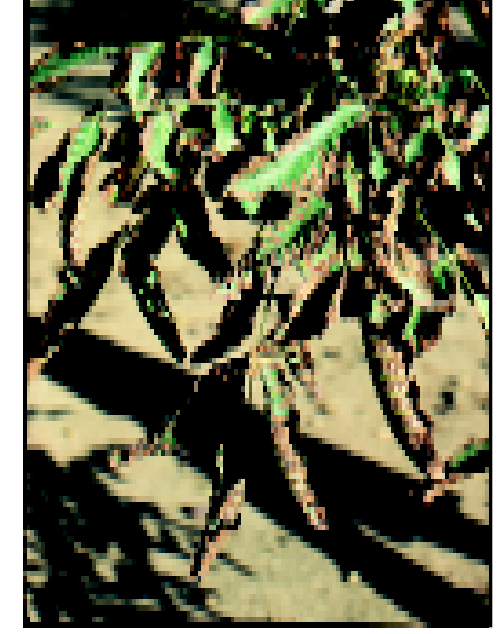

\section{3}
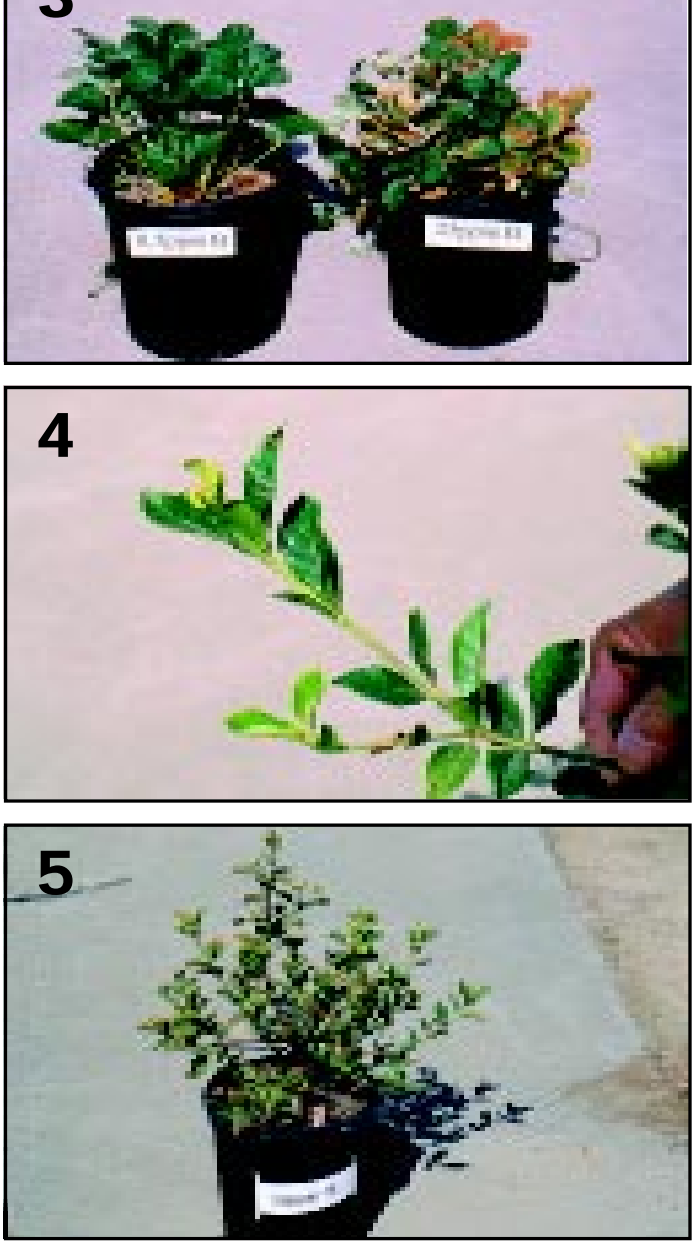
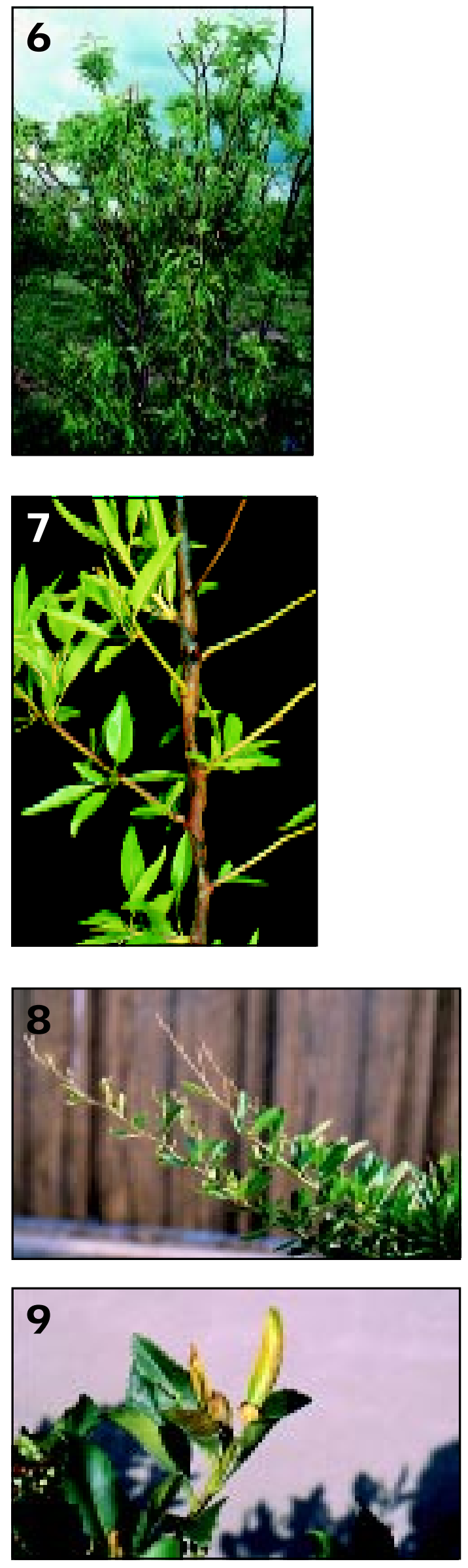

Figs. 1-10. Boron toxicity symptoms. 1), Angelica gigas, 2), Juglans regia, 3), Fragaria 'Selva', 4-5), Gardenia augusta 'Veit-chiana', 6-7), Prunus dulcis, 8), Pyracantha crenatoserrata 'Gra-beri', 9), Rhaphiolepis indica 'Pinkie', 10), Ligustrum japonicum 'Texanum'.

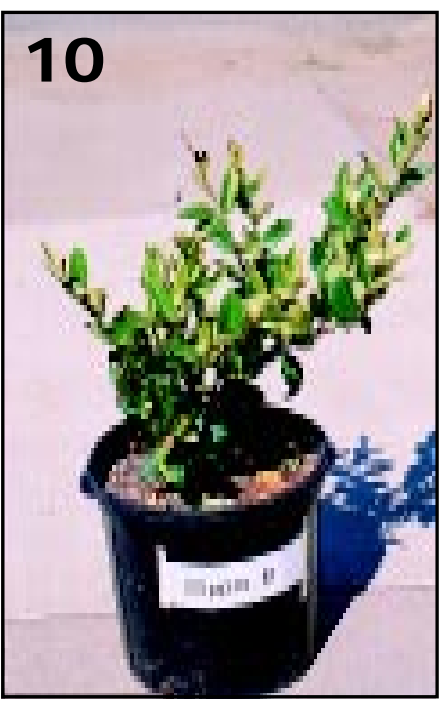


Table 1. Boron concentration in leaves of control and those expressing B toxicity symptoms. Samples were collected on 25 July or 19 Aug. 1997 as B toxicity occurred. Boron concentration was analyzed by inductively coupled plasma-mass spectrometry.

\begin{tabular}{|c|c|c|c|}
\hline \multirow[b]{2}{*}{ Species } & \multicolumn{3}{|c|}{ B concn $\left(\mu \mathrm{g} \cdot \mathrm{g}^{-1}\right.$ dry wt $)$} \\
\hline & $\begin{array}{l}\text { Leaf displaying } \\
\text { toxicity symptoms }\end{array}$ & $\begin{array}{c}\text { Control } \\
\text { leaf }^{\mathrm{z}}\end{array}$ & $\begin{array}{c}\text { Leaf } \\
\text { position }\end{array}$ \\
\hline Angelica gigas & $1252 \mathrm{a}^{\mathrm{y}}$ & $209 \mathrm{~b}$ & Basal \\
\hline Eryngium eburneum & 885 a & $195 \mathrm{~b}$ & Basal \\
\hline Fragaria 'Selva' & 1676 a & $487 \mathrm{~b}$ & Basal \\
\hline Galium odoratum & $1373 \mathrm{a}$ & $267 \mathrm{~b}$ & Basal \\
\hline Lycopersicon esculentum & $2184 \mathrm{a}$ & $752 \mathrm{~b}$ & Basal \\
\hline Potentilla alba 'Snow White' & $971 \mathrm{a}$ & $186 \mathrm{~b}$ & Basal \\
\hline Cotoneaster dammeri 'Lowfast' & 637 a & $110 \mathrm{~b}$ & Apical \\
\hline Digitalis purpurea 'Alba' & 1686 a & $374 \mathrm{~b}$ & Apical \\
\hline Gardenia augusta 'Veitchiana' & $745 \mathrm{a}$ & $169 \mathrm{~b}$ & Apical \\
\hline Ligustrum japonicum 'Texanum’ & $924 \mathrm{a}$ & $293 \mathrm{~b}$ & Apical \\
\hline Pyracantha crenatoserrata 'Graberi' & 736 a & $315 \mathrm{a}$ & Apical \\
\hline Rhaphiolepis indica 'Pinkie' & 1566 a & $392 \mathrm{~b}$ & Apical \\
\hline Veronica austriaca subsp. teucrium 'Crater Lake Blue' & $370 \mathrm{a}$ & $115 \mathrm{~b}$ & Apical \\
\hline Antirrhinum 'Liberty Mix' & $1458 \mathrm{a}$ & $126 \mathrm{~b}$ & Basal \\
\hline Forsythia $\times$ intermedia 'Lynwood' & $1465 \mathrm{a}$ & $100 \mathrm{~b}$ & Basal \\
\hline Osmanthus heterophyllus & 964 a & $227 \mathrm{~b}$ & Apical \\
\hline Spiraea prunifolia & $315 \mathrm{a}$ & $95 \mathrm{~b}$ & Apical \\
\hline Syringa vulgaris 'Lavender Lady' & $594 \mathrm{a}$ & $35 \mathrm{~b}$ & Apical \\
\hline
\end{tabular}

${ }^{\mathrm{z}}$ Leaves displaying toxic symptoms were sampled from the $25 \mathrm{mg} \cdot \mathrm{L}^{-1} \mathrm{~B}$ treatment, while the control leaves were sampled from $0.5 \mathrm{mg} \cdot \mathrm{L}^{-1} \mathrm{~B}$ treatment of the same position as those showing toxic symptoms.

y Means were compared within a species according to Fisher's protected LSD. Means with different letters differed significantly $(p<0.05)$.

Table 2 shows the $\mathrm{B}$ concentration in the leaves along a single shoot. An increasing concentration from young to old leaves is typical of a phloem-immobile element, while the opposite is true of a phloem-mobile element (van Goor and van Lune, 1980). In several species, the highest $\mathrm{B}$ concentration occurred in the basal leaves, while lowest B concentration occurred in the apical leaves, indicating that B is phloem-immobile in these species. In contrast, in other species, the opposite concentration gradient was found; the lowest $\mathrm{B}$ concentration occurred in the basal leaves, while the highest $\mathrm{B}$ concentration occurred in the apical leaves, indicating that $B$ is phloem-mobile in these species.

Comparing the leaf types exhibiting B toxicity (Table 1) with the patterns of $\mathrm{B}$ accumulation (Table 2), we can find that in the majority of species, B accumulation patterns matched very well with the leaf types exhibiting B toxicities. In other words, if the highest $\mathrm{B}$ concentration is found in the basal (oldest) leaves in a species indicating that $\mathrm{B}$ is phloem-immobile, then leaf tip/ margin burn will occur on old leaves when this species is subject to high B treatments. On the other hand, if highest B concentration is found in the apical (youngest) leaves in a species, indicating that $\mathrm{B}$ is phloem-mobile, then dieback of the meristem will occur when this species is subject to high B treatment. The appearance of B toxicity symptoms is therefore determined solely by the patterns of B distribution in the plant.

There were few species that did not strictly fit this general classification. Antirrhinum and Forsythia both exhibited basal leaf tip burn and would be expected to have a decreasing acropetal concentration gradient (i.e., lowest B concentration in the apical leaves) according to our predication. However, they showed no gradient (Table 2). This may have occurred because at the time of sampling, all the leaves of these two species were fully mature, and no young tissues were present. Osmanthus, Spiraea, and Syringa not only showed death of apical leaves in the $25 \mathrm{mg} \cdot \mathrm{L}^{-1}$ B treatment, but also some unusual symptoms when provided B at $0.5 \mathrm{mg} \cdot \mathrm{L}^{-1}$. As a result, for these species whether B toxicity will exhibit as death of apical leaves or burn of tip/margin of old leaves are uncertain.

Symptoms of B toxicity have been described previously for many other species. Whereas the majority of plant species show the typical symptoms of B toxicity including leaf tip and margin burn in old leaves (Brown and Shelp, 1997; Eaton, 1944), several species do not. Stem dieback as a result of B toxicity has been reported in several species of Prunus by Eaton et al. (1941), Hansen (1948, 1955), Woodbridge (1955), Dye et al. (1983), and El-Motaium et al. (1994). Dieback of apical or lateral shoots and cracked fruit have also been found in pear [Pyrus pyrifolia (Burm.f.) Nakai (syn. P. Serotina Rehd.)] by Choe et al. (1986). Both Prunus and Pyrus transport sorbitol (Loescher, 1987), and hence a high $B$ accumulation in the meristem or fruit can be expected in these species due to the high mobility of B (Brown and Hu, 1996, Brown and Shelp, 1997). The B-toxicity-induced dieback in L. japonicum 'Texanum' described in this experiment has also been reported in the same species by Francois and Clark (1979). Ligustrum transports mannitol in its phloem (Zimmermann and Ziegler, 1975), and hence B should be highly mobile (Brown and $\mathrm{Hu}, 1996)$. Francois (1988) also found B toxicity in young growing leaves in celery (Apium graveolens var. dulce (Mill.) Pers.] but not in old leaves. This is consistent with the results presented here because mannitol is the primary photosynthetic product and the major form of translocated carbon in celery (Davis et al., 1988). As a result, B is highly mobile in celery (Hu et al., 1997).

Some of the species we studied did not exhibit B toxicity, however the tissue in which toxicity would ultimately occur can be predicted from information of $\mathrm{B}$ distribution, if $\mathrm{B}$ accumulation patterns reflect B toxicity patterns in all species. C. $\times$ kirkii and $T$. jasminoides will probably show leaf tip/margin burn in old leaves, while $P$. crispum and $P$. granatum 'Nana' will probably show stem dieback. In M. boaria and O. europaea 'Skylark' stem dieback is likely to occur given the higher B concentrations in 
Table 2. Boron concentration in leaves of different ages along a shoot. Samples were collected on 23 Sept. 1997 from the $0.5 \mathrm{mg} \cdot \mathrm{L}^{-1} \mathrm{~B}$ treatment. Boron concentration was analyzed by inductively coupled plasma-mass spectrometry.

\begin{tabular}{|c|c|c|c|}
\hline \multirow[b]{3}{*}{ Species } & \multicolumn{3}{|c|}{ B concn $\left(\mu \mathrm{g} \cdot \mathrm{g}^{-1}\right.$ dry wt $)$} \\
\hline & \multicolumn{3}{|c|}{ Leaf position } \\
\hline & Basal & Middle & Apical \\
\hline Angelica gigas & $178 \mathrm{a}^{\mathrm{z}}$ & $134 \mathrm{a}$ & $78 \mathrm{a}$ \\
\hline Eryngium eburneum & $250 \mathrm{a}$ & $95 \mathrm{~b}$ & $64 \mathrm{~b}$ \\
\hline Fragaria 'Selva' & $512 \mathrm{a}$ & $176 \mathrm{~b}$ & $68 \mathrm{c}$ \\
\hline Galium odoratum & 399 a & $177 \mathrm{~b}$ & $92 \mathrm{~b}$ \\
\hline Lycopersicon esculentum & $721 \mathrm{a}$ & $318 \mathrm{~b}$ & $94 \mathrm{c}$ \\
\hline Potentilla alba 'Snow White' & $176 \mathrm{a}$ & $128 \mathrm{a}$ & $115 \mathrm{a}$ \\
\hline Cotoneaster dammeri 'Lowfast' & $157 \mathrm{a}$ & $190 \mathrm{a}$ & $439 \mathrm{a}$ \\
\hline Digitalis purpurea 'Alba' & $146 \mathrm{~b}$ & $335 \mathrm{~b}$ & $688 \mathrm{a}$ \\
\hline Gardenia augusta 'Veitchiana' & $73 \mathrm{~b}$ & $89 \mathrm{~b}$ & $311 \mathrm{a}$ \\
\hline Ligustrum japonicum 'Texanum' & $103 \mathrm{~b}$ & $153 \mathrm{~b}$ & $380 \mathrm{a}$ \\
\hline Pyracantha crenatoserrata 'Graberi' & $50 \mathrm{~b}$ & $66 \mathrm{~b}$ & $268 \mathrm{a}$ \\
\hline Rhaphiolepis indica 'Pinkie' & $85 \mathrm{~b}$ & $171 \mathrm{~b}$ & $425 \mathrm{a}$ \\
\hline Veronica austriaca subsp. Teucrium 'Crater Lake Blue' & $59 \mathrm{a}$ & $61 \mathrm{a}$ & $199 \mathrm{a}$ \\
\hline Antirrhinum 'Liberty Mix' & 347 a & $312 \mathrm{a}$ & $390 \mathrm{a}$ \\
\hline Forsythia $\times$ intermedia 'Lynwood' & 437 a & 387 a & $401 \mathrm{a}$ \\
\hline Osmanthus heterophyllus & $169 \mathrm{~b}$ & $204 \mathrm{~b}$ & $464 \mathrm{a}$ \\
\hline Spiraea prunifolia & $58 \mathrm{~b}$ & $51 \mathrm{~b}$ & 339 a \\
\hline Syringa vulgaris 'Lavender Lady' & $40 \mathrm{a}$ & $42 \mathrm{a}$ & $60 \mathrm{a}$ \\
\hline Coprosma $\times$ kirkii & $489 \mathrm{a}$ & $238 \mathrm{~b}$ & $66 \mathrm{~b}$ \\
\hline Maytenus boaria & $95 \mathrm{a}$ & $101 \mathrm{a}$ & $115 \mathrm{a}$ \\
\hline Olea europaea 'Skylark' & $42 \mathrm{a}$ & $51 \mathrm{a}$ & $56 \mathrm{a}$ \\
\hline Petroselinum crispum & $141 \mathrm{a}$ & 387 a & $473 \mathrm{a}$ \\
\hline Punica granatum 'Nana' & $38 \mathrm{~b}$ & $40 \mathrm{~b}$ & $155 \mathrm{a}$ \\
\hline Trachelospermum jasminoides & $665 \mathrm{a}$ & $253 \mathrm{~b}$ & $183 \mathrm{~b}$ \\
\hline
\end{tabular}

${ }^{\mathrm{z}}$ Means were compared within a species according to Fisher's protected LSD. Means with different letters differed significantly $(p<0.05)$.

apical rather than basal leaves. However, leaves on these species are long lived, and changes in photosynthetic capacity with leaf age may alter sugar alcohol export, B distribution, and symptoms.

The identification by Brown and $\mathrm{Hu}(1996)$ and $\mathrm{Hu}$ et al. (1997) that phloem B mobility and tissue B distribution are a consequence of the formation and phloem mobility of a sugar alcohol-B complex provides an explanation for the symptom expression observed here. In species used here or reported elsewhere, for which B-complexing sugar alcohols have been experimentally determined, $\mathrm{B}$ is phloem-mobile, and toxicity symptoms occur in young tissues. We predict, based upon these results that the presence of B-complexing sugar alcohols in a species will result in apical B accumulation and expression of B toxicity in young tissues of that species. In species for which sugar alcohols have not been found in any member of that family, B is immobile, and symptoms appear in old leaves (Lycopersicon), we predict this will be true for all species in which sucrose is the sole transported sugar in the phloem.

For species and families in which sugar alcohol content has not been measured it is impossible to determine B transport and toxicity patterns. Hence, we included several species in the experiment because some members of that plant family have been reported to produce B-complexing sugar alcohols. Of the species in this group several (G. augusta 'Veitchiana' and L. japonicum 'Texanum') were clearly B transporters and exhibited apical B toxicity, while others (A. gigas and E. eburneum) were not and exhibited B toxicity in basal leaves. On the basis of this work and the results reported by others we conclude that B is phloemmobile and hence B toxicity will be expressed in young tissues of species within the Rosaceae, Oleaceae, Rubiaceae, Scrophul- ariaceae, Apiaceae, and Celastraceae. Not all species within these families necessarily exhibit B mobility and the consequent B toxicity symptoms, for example, Fragaria and Potentilla (Rosaceae), and Angelica and Eryngium (Apiaceae) do not exhibit B mobility while other members of the same family do [e.g., Cotoneaster, Pyracantha (Rosaceae) and Petroselinum (Apiaceae)].

Patterns of B toxicity in species with phloem B mobility would not be recognized by many horticulturists and could easily be mistaken for other diseases and physiological disorders. For example, the symptoms of B toxicity in the species of Cotoneaster, Prunus, Pyracantha, Pyrus, and Rhaphiolepis are similar to those caused by fire blight (Erwinia amylovora) and could only be definitively separated by B analysis of affected organs. In summary, this report provides new insight into the determination of $\mathrm{B}$ toxicity in diverse species and should help identify problems in commercial and residential horticultural practice.

\section{Literature Cited}

Bieleski, R.L. 1982. Sugar alcohols, p. 158-192. In: F. Loewus and W. Tanner (eds.). Encyclopedia of plant physiology (NS). vol. 13A. Springer-Verlag, Berlin.

Bourne, E.J. 1958. The polyhydric alcohols. Acyclic polyhydric alcohols, p. 345-361. In: W. Ruhland (ed.). Encyclopedia of plant physiology. VI. Formation, storage, mobilization, and transformation of carbohydrates. Springer-Verlag, Berlin.

Brown, P.H. and H. Hu. 1994. Boron uptake by sunflower, squash and cultured tobacco cells. Physiol. Plant. 91:435-441.

Brown, P.H. and H. Hu. 1996. Phloem mobility of boron is species dependent: Evidence for phloem mobility is sorbitol-rich species. Ann. Bot. 77:497-505. 
Brown, P.H. and H. Hu. 1998. Phloem boron mobility in diverse plant species. Bot. Acta. 111:331-335.

Brown, P.H. and B.J. Shelp. 1997. Boron mobility in plants. Plant Soil 193:85-101.

Choe, J.S., J.C. Lee, S.B. Kim, and J.Y. Moon. 1986. Studies on the cause of shoot dieback in pear trees (Pyrus serotina Rehder). J. Korean Soc. Hort. Sci. 27:149-156.

Croughan, T.P. and D.W. Rains. 1982. Terrestrial halophytes: Habitats, uses and productivity, p. 245-255. In: A. Mitsui and C.C. Black (eds.). Handbook of biosolar resources. Part 2. Basic principles. CRC Press, Boca Raton, Fla.

Davis, J.M., J.K. Fellman, and W.H. Loescher. 1988. Biosynthesis of sucrose and mannitol as a function of leaf age in celery (Apium graveolens L.). Plant Physiol. 86:129-133.

Dye, M.H., L. Buchanan, F.D. Dorofaeff, and F.G. Beecroft. 1983. Dieback of apricot trees following soil application of boron. N.Z. J. Expt. Agr. 11:331-342.

Eaton, F.M, R.D. McCallum, and M.S. Mayhugh. 1941. Quality of irrigation waters of the Hollister area of California. USDA Tech Bul. No. 746.

Eaton, F.M. 1944. Deficiency, toxicity and accumulation of boron in plants. J. Agr. Res. 69:237-277.

El-Motaium, R., H. Hu, and P.H. Brown. 1994. The relative tolerance of six Prunus rootstocks to boron and salinity. J. Amer. Soc. Hort. Sci. 119:1169-1175.

Francois, L.E. 1988. Yield and quality responses of celery and crisphead lettuce to excess boron. J. Amer. Soc. Hort. Sci. 113:538-542.

Francois, L.E. 1991. Yield and quality responses of garlic and onion to excess boron. HortScience 26:547-549.

Francois, L.E. and R.A. Clark. 1979. Boron tolerance of twenty-five ornamental shrub species. J. Amer. Soc. Hort. Sci. 104:319-322.

Hansen, C.J. 1948. Influence of rootstock on injury from excess boron in French (Agen) prune and President plum. Proc. Amer. Soc. Hort. Sci. 51:239-244.

Hansen, C.J. 1955. Influence of rootstock on injury from excess boron in Nonpareil almond and Elberta peach. Proc. Amer. Soc. Hort. Sci. 65:128132.
Hoagland, D.R. and D.J. Arnon. 1950. The water-culture method for growing plants without soil. Calif. Agr. Expt. Sta. Circ. 347.

Hu, H., S.G. Penn, C.B. Lebrilla, and P.H. Brown. 1997. Isolation and characterization of soluble B-complexes in higher plants. Plant Physiol. 113:649-655.

Loescher, W.H. 1987. Physiology and metabolism of sugar alcohols in higher plants. Physiol. Plant. 70:553-557.

Maas, E.V. 1984. Salt tolerance of plants, p. 57-75. In: B.R. Christie (ed.). Handbook of plant science in agriculture. vol. 2. CRC Press, Boca Raton, Fla.

Makkee, M., A.P.G. Kieboom, and H. van Bekkum. 1985. Studies on borate esters III. Borate esters of D-mannitol, D-glucitol, D-fructose and D-glucose in water. Rec des Tra. Chim. Pays-Bas. 104:230-235.

Nyomora, A.M.S., R.N. Sah, P.B. Brown, and R.O. Miller. 1997. Boron determination in biological materials by inductively coupled plasma atomic emission and mass spectrometry: effects of sample dissolution methods. Fresenius J. Anal. Chem. 357:1185-1191.

Oertli. J.J. 1960. The distribution of normal and toxic amount of boron in leaves of rough lemon. Agron. J. 52:530-532.

Oertli, J.J. 1994. Non-homogeneity of boron distribution in plants and consequence for foliar diagnosis. Commu. Soil Sci. Plant Anal. 25:11331147.

Plouvier, B. 1963. Distribution of aliphatic polyols and cyclitols, p. 313 336. In: T. Swain (ed.). Chemical plant taxonomy. Academic Press, New York.

Wallaart, R.A.M. 1980. Distribution of sorbitol in Rosaceae. Phytochemistry. 19:2603-2610.

Woodbridge, C.G. 1955. The boron requirements of stone fruit trees. Can. J. Agr. Sci. 35:282-286.

van Goor, B.J. and P. van Lune. 1980. Redistribution of potassium, boron, magnesium and calcium in apple trees determined by an indirect method. Physiol. Plant. 48:21-26.

Zimmermann, M.H. and H. Ziegler. 1975. List of sugars and sugar alcohols in sieve-tube exudates, p. 480-503. In: Zimmermann M.H. and J.A. Milburn (eds.). Encyclopedia of plant physiology. V1. Transport in plants. I. Phloem transport. Springer-Verlag, Berlin. 